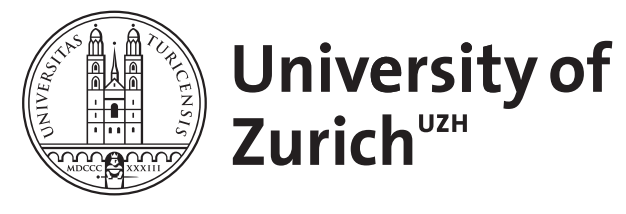

\title{
How Influential is Economics?
}

Frey, Bruno S

\begin{abstract}
Economists often claim that their discipline has a great influence on the economy. An analysis of the existing literature reveals, however, that little convincing empirical evidence exists. The two approaches used are subject to major shortcomings. The "Economics Production Function" relating the input of economic ideas to economic outcomes, is faced with major estimation problems. The "Revealed Behaviour Approach" of choosing to study economics is based on very restrictive assumptions. It is argued that the "Case Study Approach" analysing specific policy instances constitutes a more promising avenue and should be undertaken to identify more general patterns of influence.
\end{abstract}

DOI: https://doi.org/10.1007/s10645-006-9005-2

Posted at the Zurich Open Repository and Archive, University of Zurich ZORA URL: https://doi.org/10.5167/uzh-2466

Journal Article

Published Version

Originally published at:

Frey, Bruno S (2006). How Influential is Economics? De Economist, 154(2):295-311.

DOI: https://doi.org/10.1007/s10645-006-9005-2 
DE ECONOMIST 154, NO. 2, 2006

\title{
NOTES AND COMMUNICATIONS
}

HOW INFLUENTIAL IS ECONOMICS?

\author{
Summary
}

\begin{abstract}
Economists often claim that their discipline has a great influence on the economy. An analysis of the existing literature reveals, however, that little convincing empirical evidence exists. The two approaches used are subject to major shortcomings. The 'Economics Production Function' relating the input of economic ideas to economic outcomes, is faced with major estimation problems. The 'Revealed Behaviour Approach' of choosing to study economics is based on very restrictive assumptions. It is argued that the 'Case Study Approach' analysing specific policy instances constitutes a more promising avenue and should be undertaken to identify more general patterns of influence.
\end{abstract}

Key words: economic policy, economics, economists, influence, politics

JEL Codes: A11, A12, A13, B40, F20, J20

\section{INTRODUCTION}

Economics is often taken to be the 'Queen of the Social Sciences'. There is a higher degree of consensus about its approach and content than in many other social sciences (such as, for instance, in sociology or psychology). Many economists jump to the conclusion that they do have considerable influence on society. They believe that economics makes a major and beneficial contribution to the solution of economic and social problems. They routinely refer to the many economists called as policy advisors, and the prominent positions some economists have attained in politics. But such activities refer to the influence economics may have on the input side. Whether economics as a discipline has indeed an effect on the economy refers to the outcome or output side. Economists' input may or may not have an impact; and it may raise or lower social welfare. The widespread belief among economists of the large effect of economics on society is (at least so far) not based on any convincing empirical evidence.

This communication is part of the emerging field of the 'Economics of Economics' (e.g. van Bergeijk et al. (1997); Mäki (1999); Van Dalen (2003); Coupé (2004); Kirchgässner (2005)), but it does not intend to provide a general survey. 1 Rather it focuses more narrowly on how the influence of economics and economists can be empirically identified.

1 See, for instance, for recent contributions with extensive references to the literature Stephan's (1996) survey on the "Economics of Science", Frey and Eichenberger (1993, 1997), 
Section 2 shortly reviews some well-known claims made by economics scholars regarding the influence of their discipline. The following section critically discusses two major avenues that have been used to capture the influence of economics and economists: The 'Economics Production Function Approach' and the 'Revealed Preference Approach' in terms of individual's decision to study economics. Section 4 argues that a more useful avenue is the 'Case Study Approach' analysing particular policy events. The last section sketches aspects to be considered in order to make progress in evaluating the influence of economics and economists.

\section{CLAIMS ABOUT THE INFLUENCE OF ECONOMICS AND ECONOMISTS}

The best-known statement about the influence of economists is due to Keynes (1936, p. 383): "(T)he ideas of economists and political philosophers ... are more powerful than is commonly understood. Indeed the world is ruled by little else." Interestingly enough, in Keynes' statement, economists share this position with political philosophers, who by most other people are rarely assumed to have much (direct) influence on the world. Hayek (1991, p. 37) agrees with Keynes, but adds that "... economists have this great influence only in the long run and indirectly". Similar views of the strong achievement and impact of economics have more recently been put forward by Dasgupta (1998) or Baumol (2000, p. 38), who writes: "In our discipline, the century has been full of accomplishments. New ideas, new directions, and powerful new tools have emerged in the profession. Evidently, our field of study is alive and well." The former US Secretary of the Treasury, now President of Harvard University and noted professor of economics, Summers (2000, p. 1) clearly expresses the notion that economists have a great impact on society when he states that "(w)hat economists think, say, and do has profound implications for the lives of literally billions of their fellow citizens".

But there are also contrasting claims. The Economist (1997, p. 13) writes about the "Puzzling Failure of Economics" and, concerning the future of economics (2000, p. 90), asks: "In the long run, is the subject dead?" Indeed, in recent years the media have increasingly turned to so-called 'analysts' working in the financial sector who interpret economic events exclusively with respect to their impact on share prices. The New Yorker (Cassidy (1996, pp. 50-51)) comments "... a good deal of modern economic theory, even the kind that wins Nobel Prizes, simply does not matter much". Cassidy argues that today's leading economists are often unknown beyond their narrowly defined field; only a few books written by academic economists catch the attention of the general public (see also Blendon (1997)). According to that article, politicians 
are less and less interested in the economics literature, but turn to academics with a higher profile from other fields.

It may well be argued that these are journalistic statements not to be taken seriously. But similar views have also been advanced in the academic discourse. Clower (1989, p. 23), a former editor of the American Economic Review, states that "(m)uch of economics is so far removed from anything that remotely resembles the real world that it is often difficult for economists to take their subject seriously." Even Nobel Prize recipients in economics, such as Leontief (1971), Coase (1994) or Buchanan (2000), criticise their field for its lack of involvement in real life issues. The most devastating judgement is, however, made by Blaug (2002): "Modern economics is sick; economics has increasingly become an intellectual game played for its own sake and not for its practical consequences".

Other academic economists seem to accept that economics does affect society, but are critical of whether or not this influence has been beneficial. One, not surprisingly, is Galbraith (1975), writing "the economic profession - I choose the words with care - is intellectually bankrupt. It might as well not exist". A similar statement has been made from the ideologically opposite side, namely by Friedman (1972, p. 12): "We economists in recent years have done vast harm - to society at large and to our profession in particular by claiming more than we can deliver".

These are some of the claims made about the effect of economics and economists on society (see also the excellent accounts in Middleton (1998), Reder (1999) $)^{2}$. In order to make more definite statements about the effect of economics, theoretical approaches need to be identified and the respective empirical evidence scrutinized.

\section{EXISTING APPROACHES}

Two approaches have been used in an effort to identify and measure the effect of economics and economists on the economy: A macro-economic approach based on estimating a Production Function for economics (subsection A) and micro-economic approach using Revealed Behaviour in terms of choosing to study economics (subsection B). Both are shown to be subject to grave shortcomings.

2 Many studies deal with the application of economics to real life issues but are little, or not at all, concerned with the question of whether these applications have been put into practice and have had any effect. A good example is the survey by Baumol (2000), whose central contention is that "theory, empirical investigation, and application" (p. 30) have been integrated. But even this contention is not undisputed; thus Reder $(1999$, p. 330) writes "... the salient factor is the relative weakness of the link between theory and application in economics." 


\subsection{Macro-Economic Approach: Economics Production Function}

The influence of economics and/or economists on the economy and society may be analysed by systematically linking the input provided by economics to the outcome in the form of the state of the economy, i.e. by empirically estimating an aggregate Economics Production Function. The state of economy S can be modelled to depend on three input factors: economic theory $\mathrm{E}$, other social sciences $\mathrm{O}$, and additional factors $\mathrm{A}$.

$$
\mathrm{S}=\mathrm{f}(\mathrm{E}, \mathrm{O}, \mathrm{A})
$$

The state of the economy S can be captured in various ways. Relevant possibilities are the level or the rate of growth of per capita income, the rate of unemployment, the rate of inflation, the value of the stock of firms traded at the stock exchange. Recently, the concept of the national income has been extended by measuring subjective well-being or happiness (see e.g. Frey and Stutzer (2002), Layard (2005)). A more partial indicator would be, for instance, the intensity of innovative activity. The input by economics and/or economists $\mathrm{E}$ can be measured by the number, share or growth rate of economists, or by the number and quality of research articles published and quoted. Obviously, these measures may be convenient, and data may be available, but they can hardly do justice to the definitional problems discussed in the previous subsection. The input by other sciences (variable $\mathrm{O}$ ) can be captured by the corresponding figures for political science, policy science, sociology or law. The factor $\mathrm{A}$ is a vector of variables capturing all other determinants unrelated to the influence of either economics or the other social sciences. They can range, for instance, from foreign exchange crises to technological innovations, from natural disasters to political events such as wars. The factors $\mathrm{O}$ and $\mathrm{A}$ are controls serving to capture the influence of economics in an unbiased way. It need not be emphasized that all this is easier said than done.

There are many different views as to how the functional relationship might look. A very negative one is from Allen (1979, pp. 18-19) writing that “... a country's economic progress is in inverse proportion to the distinction of its economists". Wyplosz (1999, p. 60) claims that there is no relationship: "The economic successes of France and Japan seem to indicate that economic policy can be carried out perfectly well without economics". Stigler (1982, p. 63) believes that "(e)conomists exert a minor and scarcely detectable influence on the societies in which they live"3.

3 For other analyses linking economics to policy see e.g. Blankart (1981), Peacock (1991, 1992), Hamilton (1992) and Jones and Cullis (1993). 
To my knowledge, the Economics Production Function for economics has not been estimated ${ }^{4}$, with the exception of Barro (1993), who jokingly described the relationship between the economists in the US Council of Economic Advisors and the state of the economy in the following way:

“... economic outcomes (measured by the contribution to the misery index) and the credentials of the chairman of the council (measured by citation counts) are essentially uncorrelated. Although some who are highly ranked on citations ... do well on performance, the highly ranked Mr. Schultze ends up with the worst economic outcomes. Moreover, some of the chairmen who ranked low on citations ... emerge with good economic performance" 5 .

Estimates of 'spillovers' on commercial innovations of academic research, as undertaken e.g. by Jaffe (1989) or Acs et al. (1991), may be interpreted as a special variant of scientific Economics Production Functions.

Formulating an Economics Production Function offers one distinct advantage. Attention is focussed on a clear separation between input and output of economics, a distinction often overlooked when discussing the importance of economists. Formulating an Economics Production Function helps to overcome a major shortcoming of many claims, which presume as a matter of course that offering economic advice, and being active as a politician, is the same as actually influencing the course of society. An Economics Production Function also makes clear that the state of the economy depends on a great many factors, and that the input of economic ideas and of the activities by economists is only one of them. It helps to avoid the special interest view which attributes economic successes to economics and economists, while economic failures tend to be attributed to other influences or bad luck. The approach is also useful as it is explicitly based on a comparative view: There are representatives of many other disciplines, such as for example lawyers or political scientists, who influence the state of the economy. Even if the role of economists can be empirically established, it could still be possible that their influence is minor compared to other disciplines.

There are, however, serious disadvantages to the Economics Production Function Approach. Most importantly, causality cannot be established, at least with the data normally at hand. The construction of a Production

4 Cicarelli and Spizman (1984) specify a "production function for economic knowledge", where the departments of economics at major universities are taken to be the firms responsible for producing the output of the special knowledge industry, namely economics itself.

5 Magee (1992) estimated an economics production function for lawyers using a cross-section analysis for 54 countries. Taking into account various other factors (F), it turns out that lawyers have an inverted U-shaped influence on economic growth, i.e. there is an optimal number of lawyers. Having too many lawyers produces major negative external effects. 
Function assumes that the input of economics is an exogenous factor (partially) determining the economic outcomes. The coefficient showing the effect of economics on outcomes can be seriously biased if economics is in turn influenced by economic outcomes. The causation is likely to be also in the reverse direction: Economists start studying issues when they have become visible in society. Moreover, the services of economists may well be requested only when there are problems in society for which politicians and public officials cannot find an easy answer. Economic ideas may well affect society only indirectly, as suggested by Hayek (1991, p. 37). A variable can simultaneously affect both economic science and society, so that a correlation is only seemingly causal. The time lag between the economic ideas being proposed and the effect on society is moreover uncertain ${ }^{6}$. The scarcity of data will normally make it impossible to empirically determine the lag structure as a whole. Finally, the basic prerequisites for estimating an Economics Production Function are not fulfilled: ".. the market [for economics] at the production possibility frontier is inefficient in the sense that, given the output of pure theory, we could achieve a better output of applied work. We are not at the production possibility frontier" (Mayer (1993, p. 10)). These problems make it practically impossible to identify the effect of economics on economic outcomes.

These shortcomings are serious. They suggest that an econometric estimation of an aggregate Economics Production Function is unlikely to be successful even if the major data problems could be overcome.

\subsection{Revealed Preference: The Choice of Studying Economics}

An indirect, more micro-economic, way to study the influence of economics on society is to analyse Revealed Behaviour. When individuals choose their subject of study, in addition to their intrinsic interest in the discipline they (at least implicitly) also take into account the future demand for their services and the corresponding income situation. The larger the expected contribution to society of a person trained in economics, the greater will be this demand. As a consequence, the influence of economists on society is reflected in the share of persons deciding to study economics and in their income. In so far as this demand is fully reflected on a monetary market, a larger influence is visible in higher average compensation compared to persons who studied other disciplines.

The Revealed Preference Approach can also be applied at later stages of the career. If economists influence society in their role as practitioners

6 For example, Schelling (1997, p. 146) states that it took twenty years until economic proposals entered environmental policy, but such a dating is certainly open to debate, and varies considerably in extent according to the area or country. Hayek (1991, p. 37) vaguely speaks of a "long run" effect, leaving it open whether he means five, ten, twenty or even more years. See, in general, Colander and Coats (1989). 
there will be a higher demand for their services, and there will be both a higher number and they will enjoy higher income. This holds in particular for being employed in the public administration (see Coats $(1981,1989)$ ) in international organisations (Coats (1986)), and in public or private research institutes (e.g. Cockett (1995)). They can establish consultancy companies, a sector which recently mushroomed in the USA and elsewhere, and may appear as expert witnesses (Mandel (1999, p. 115); Posner (1999)). There are also many economists who have achieved distinguished positions in politics. Restricting to professors of economics and just taking two countries as examples, in the Netherlands Lubbers, Zijlstra, and De Quay were prime ministers, Andriessen, Duisenberg, Witteveen and Zalm ministers of finance, and Pronk and Ritzen were ministers in other departments. At the federal government level in Germany, Erhard was a professor of economics becoming chancellor, Schiller became finance minister, and Töpfer and Hankel served as heads of other ministries. Influence can also be expected when economists serve as advisors in public institutions, such as the US Council of Economic Advisors or the German Sachverständigenrat (see, recently, Schultze (1996); Feldstein (1997); Stein (1997); Stiglitz (1997)), or other academic advisory boards attached to ministries. Academic economists can also act as indirect suppliers through their research activities and teaching, thus shaping the knowledge of a future generation of economists.

The demand for economists is partly produced by the economics profession itself. Economic theories favouring government intervention increase the demand for economists in public advisory boards and within the public administration ${ }^{7}$. According to Friedman (1986, pp. 8-9), one reason why Keynesian theory became accepted so quickly was that "... it opened up such wonderful opportunities for employment and influence by economists ... the New Deal was the greatest employment programme for economists that ever existed". In the $80 \mathrm{~s}$, the policy of privatisation and deregulation also increased the demand for economists in the private sector.

The choice to study economics as a discipline shows considerable variation. Consider the United States where the number of students majoring in economics dropped drastically by 30 per cent between 1992 and 1996, while the number of doctoral students fell by 18 per cent in the same period (Siegfried (1998)). Moreover, a considerable number of American PhD graduates in economics leave the country later (Siegfried and Stock (1999, pp. 116-118)), indicating an even more drastic decline in the number of US American students embarking on a $\mathrm{PhD}$ programme. This interpretation is also supported by the fact that many $\mathrm{PhD}$ programmes at American universities rely on foreign participants for their survival. The United Kingdom (Middleton (1998, p. 360); Machin and Oswald (1999)) faces a similar problem. In Germany,

7 But there is a free-riding problem involved: an individual economist has little incentive to produce the public good of higher demand. 
university departments of economics are threatened by the lack of students while business economics flourishes. Teaching or carrying out research in economics seem to have lost some of their appeal. Many talented young students no longer see general economics as an option. Instead, they move toward specialising in finance, labour and resource economics, with the intention of finding a job outside academia. A degree in general economics does not seem to be necessary, nor sufficient for a practical career (see also Hansen (1999), Krueger (1999) and the reports to the American Economic Association and the Royal Economic Society by Krueger et al. (1991) and by Towse and Blaug (1998) respectively). Just 3 per cent of American graduates consider a thorough knowledge of the economy as crucial for their exams, as opposed to 57 per cent, who regard first class knowledge of mathematics as decisive. A further 65 per cent think that the ability to solve formal problems is vital. Students of economics are reported to be increasingly dissatisfied with their field (Siegfried and Stock (1999, p. 130), see also Colander and Klamer (1987)). According to Krueger (1999, p. 155) "business and public policy schools ... begin training their own PhDs rather than drawing heavily on the output of economics departments".

In a well-functioning, perfect market without external effects or monopolistic structures, the wages paid for economists reveal their presumed influence on society. In the case of the private sector the necessary conditions are likely to be met: "... the ability to command large sums for economic expertise helps provide a market-based validation of the worth of studying economics" (Mandel (1999)). Consider again the United States where universities are more exposed to a market setting than in most other countries. Real average incomes of $\mathrm{PhDs}$ in economics dropped by 4.6 per cent in the period 1987-1995, despite the fact that the length of time spent on education had increased by 6 per cent in the same time. In other words, the rate of return on human capital has continuously dropped since 1987 (Siegfried and Stock (1999, p. 132)). The income differential also widened, if economists are compared with other qualified professionals, among them persons in entertainment, sports, and managers of large enterprises (Ehrenberg (1999, pp. 137-140)). It should however, be noted that in most countries today's university system does not correspond to a well-functioning market. Entry is severely limited and incomes are fixed by administrative rules. The incomes of academics therefore do not, or only imperfectly, reflect the evaluation of the influence of economists on society.

The indirect approach of looking at Revealed Behaviour suggests that, at least for the United States, economic ideas transmitted by persons educated in this discipline have a smaller influence on society than they did in earlier periods. This is reflected in relatively lower compensation and fewer persons majoring in economics. This statement must be seriously qualified. The conclusion rests on important conditions. The most important ones are that 
the persons involved must be reasonably well informed, so that they react to changing circumstances in an appropriate way. The choice of studying economics must react significantly, and within a reasonable time span, to changes in the perceived usefulness of economics to society. The effect on economists' relative wages is visible only if the increased demand noticeably affects monetary compensation. This is more likely to be the case for the market economy than for the non-private sector. Market wages only fully reflect usefulness to society when external effects are absent. All these are very stringent conditions making it doubtful whether the Revealed Preference Approach is useful to empirically measure the influence of economists on economic outcomes.

\subsection{Evaluation}

The discussion of the two approaches leads to a clear conclusion: Both the Economics Production Function and the Revealed Preference Approach have serious shortcomings. Even if better data were available, the two approaches are unlikely to be able to convincingly demonstrate the effect of economics and economists on economic outcomes.

\section{A MORE FRUITFUL APPROACH: CASE STUDIES}

The Case Study Approach analysing specific policy instances seems to constitute a more promising approach than the econometric estimation of an Economics Production Function or the analysis of Revealed Behaviour by individuals studying economics. It is argued that future research should concentrate on a considerable number of case studies in specific historical policy episodes. The knowledge gained may allow us to identify general patterns of influence of economics on society.

So far, there are only a few case studies empirically analysing the effectiveness of economic ideas. As Klamer and Meehan (1999, p. 65) note, "the lack of research on the actual importance of economists and their science on politicians and their policies is astonishing", and, one may add, the same is even more true for the influence on policy outcomes.

Schelling (1997) discusses many different areas in the United States in order to isolate the influence of economics on policy making: abortion, race relations, illegal drugs, crime and punishment, health care, budgetary, defence and environmental policy. He "observes how little difference economic analysis appears to make in most important policies" (Schelling (1997, p. 134)). He emphasizes that his study only relates to the United States and that conditions may be different in other countries.

Cordes et al. (1993) find that the influence of economic ideas on the American tax reform of 1986 was only minor. They even propose that economists may have had some influence, but not economics. Concerning the establishment of NAFTA, Klamer and Meehan (1999, p. 1) conclude: “... 
political arguments crowd out serious economic arguments ... academic economists had no role to play when it came to the final act". Similar views are aired by Cassidy (1996) (see also Krugman (1995)) with respect to the reform of the American health and welfare system. The same has also been observed in a study for Germany (Wilke (1999)). It looks at the influence of economic ideas proposed by economic advisory councils and by the Council of Economic Experts (Sachverständigenrat) to government departments regarding the financing of public health insurance (the Pflegeversicherung).

Research on how economic ideas enter - or fail to enter - political decisions are only in the initial stages. In particular, the role of the media has received very scant attention. According to Rivlin (1987), the media pick up some economic ideas, especially when they are controversial, yet ignore other economic ideas. But even when the media do report economic ideas, it remains an open question whether they succeed in putting economic knowledge into action.

It should be noted that these case studies refer to the impact of economics on policy. But even if economics would indeed influence policy (which, according to these studies is doubtful) it is still open whether there is any effect on societal outcomes. It cannot be excluded that in those cases in which economics influences policy, the policy is ineffective.

\section{FUTURE RESEARCH}

This communication critically discussed two approaches used to empirically capture the influence of economics and economists on the state of the economy. It has been shown that both econometrically estimating an Economics Production Function and analysing individuals' Revealed Behaviour in terms of choosing economics have major shortcomings. Even if the required data were fully available, they are unlikely to provide satisfactory answers to the question to be analysed.

It is argued here that the Case Study Method is best able to produce valuable insights into how, and to what extent, economics and economists influence the economy in particular instances and sectors. Future research should undertake a substantial set of case studies of specific historical episodes to try to identify general patterns of influence. However, results from case studies are difficult to generalise. Moreover, the existing studies focus on the influence of economics on policy, rather than on outcomes. To get a more complete picture, it is necessary to also analyse the effect of economics and economists on the state of the economy. This is a long way to go.

Before making further progress the research studying the influence of economics has to come to terms with the following issues ${ }^{8}$ :

8 See also the considerations in Klamer and Meehan (1999, pp. 65-69) and in Garnett (1999, p. 5). 
(1) What 'economics' means is not clearly defined. But many economists such as the prominent US policy advisor, Schultze (1996, p. 26), are convinced that " $(t)$ here is a distinct consensus among economists", namely the socalled 'Washington Consensus' (see Williamson (1994)). It does not only designate what such advisors take to be relevant for the United States but far beyond because 'Washington' here also refers to the international financial institutions of the World Bank and the International Monetary Fund. This consensus has been claimed to encapsulate "the common core of wisdom embraced by all serious economists" (see Middleton (1998, p. 344)). Its major recommendations are that an active economic policy should fight microeconomic distortions, while safeguarding the macroeconomic equilibrium, in particular by balancing the state budget. 'Typically economic' proposals have been identified by Reder (1999, chapter 11) and Stigler (1982) to be, for instance, the notion of an independent central bank (see Blinder 1997), free trade, privatisation or deregulation (the latter two are regarded as "success stories" by Nelson (1987)). On the microlevel, typically 'economic' instruments are market-based environmental taxes, vouchers, negative income tax, road and peak load pricing (Faulhaber and Baumol (1988); Baumol (2000)), pay for performance, stock options (e.g. Prendergast (1999)), or auction rules for the allocation of, for example, radio and TV frequencies (e.g. Joskow et al. (1998)).

The actual extent of the consensus existing among professional economists has been the subject of several empirical studies ${ }^{9}$. These surveys asked professional economists their opinions on concrete theoretical and policy issues. Considerable differences in opinions were identified. Professional economists certainly do not agree on what 'good economics' is. There is, however, more consensus among American economists (who adhere more strictly to neo-classics) than among European economists (more of whom hold Keynesian views) and with respect to microrather than to macro-economic issues. The dissent identified can partly be explained by historical and institutional differences. Thus, for example, in the 80s, French and Austrian economists were much more inclined to welcome government intervention in the economy than were American, Swiss and German economists. It would be a mistake to assume that there is a generally accepted 'economic view'. Hence it is not possible to make any general claims about the influence of economics on society. Because there are such divergent views as to what economics is, any

9 For the United Kingdom, Brittan (1973) and Machin and Oswald (1999); for the United States, Kearl et al. (1979), Alston et al. (1992); for several European countries including France, Germany, Austria and Switzerland, Frey et al. (1984). van Dalen and Klamer (1997) discuss the views of various schools of economics in the Netherlands and Fuchs et al. (1997) and Samuels (1980) analyse the consensus with respect to public finance and foreign trade issues. 
serious research must first carefully define what one refers to. An obvious possibility would be to define the 'neo-classical textbook orthodoxy' represented in the leading American textbooks to be what economic theory is, and the 'Washington consensus' to be what economic policy proposals are. It must be kept in mind that the many professional economists who do not accept these definitions will not feel represented by whatever results are reached.

(2) 'Economic' ideas can originate from both economists and non-economists; they may come indirectly through other disciplines which have adopted economic ideas; and they may be similar, or even the same, as ideas coming from other disciplines. They can be produced in organizations, such as think tanks, research institutes, scientific networks, foundations or private consultancy firms, with people from many different disciplines contributing. Economic ideas may also indirectly affect the economy and society via other fields. The extent of "economic imperialism" (Stigler (1984); Lazear (2000)) has been taken to be “... an important indicator of the success of economics" (Demsetz (1997, p. 1)). It is also important to distinguish between economic ideas, which actively want to bring about a change for the better, and those which want to prevent a change for the worse. Economists such as Krugman (1996) and Schultze $(1996$,

p. 31) argue that the main contribution of economics is to prevent 'major blunders'. In all these cases it is difficult, and often impossible to separate influences coming from economics from those originating elsewhere.

(3) The term 'influence' is open to many interpretations. In this regard the Economic Production Function Approach provides a useful framework. It shows in particular that the influence by economics and economists is at best marginal (in the sense of micro-economics but not necessarily in the sense of size). The term 'influence' suggests a unidirectional impact of economics on outcomes in society. But it must be taken into account that social conditions in turn influence economic science. As is well known from econometrics, to establish a causal influence when there is a mutual interaction is most difficult, and often impossible especially when the underlying data are weak (which is certainly true for the case here considered).

(4) The term '(policy) outcome' is ill defined. It may range from an outcome pertaining to a particular sector of the economy to overall measures such as national income or aggregate life satisfaction. In the case of partial indicators of outcome, possible substitution effects must be taken into account. Thus, economic advice may indeed have an impact on a particular activity, but it may at the same time be overcompensated by counteractive changes in other areas. 
(5) The effect of economics on societal outcomes may occur over an extended, but unknown, period of time. Here again the Economic Production Function Approach is helpful to conceptually disentangle the possible time lags. When economic advice has no identifiable effect on outcomes in a given period, this does not mean that there is none. But conversely, care must be taken not to attribute some random effect to the influence of economics solely because this effect takes place with a 'reasonable' time delay.

It should be noted that it does not make sense to determine in general how 'economics', 'influence' or 'outcome' is defined. Rather, the appropriate definition must be chosen to suit the question the particular study wants to answer. There is still a long way to go before research will have produced convincing empirical evidence about the influence of economics and economists on economic outcomes. Until such progress has been made, economists in their scientific capacity should be careful about making general claims about the influence of economics on the economy.

Bruno S. Frey*

\section{REFERENCES}

Acs, Z.J., D.B. Audetsch and M.P. Feldman (1991), 'Real Effects of Academic Research: Comment,' American Economic Review, 82(1), pp. 363-367.

Allen, R.G.C. (1979), The British Disease: A Short Essay on the Nature and Causes of the Nation's Lagging Wealth, 2nd edn., IEA, London.

Alston, R.M., J.R. Kearl and M.B. Vaughan (1992), 'Is There a Consensus among Economists in the 1990s?', American Economic Review, 82(2), pp. 203-209.

Barro, R.J. (1993), 'Council of Economic Irrelevance,' Wall Street Journal, January 12th 1993.

Baumol, W.J. (2000), 'What Marshall Didn't Know: On the Twentieth Century's Contributions to Economics,' Quarterly Journal of Economics, 115(1), pp. 1-44.

Bergeijk, P.A.G. van, A.L. Bovenberg, E.E.C. van Damme and J. van Sinderen (1997), Economic Science and Practice: The Roles of Academic Economists and Policy-Makers, Cheltenham, UK, Edward Elgar.

* Bruno S. Frey is professor of economics at the University of Zurich, Institute of Empirical Economic Research, Bluemlisalpstr. 10, 8006 Zurich, Switzerland; tel.: +41-44-634 3731 fax: +41-44-634 4907; e-mail: bsfrey@iew.unizh.ch. He is research director at CREMA - Center for Research in Economics, Management and the Arts.

For useful comments and suggestions, I am indebted to Jürgen Backhaus, Matthias Benz, Jeff Biddle, Charles Beat Blankart, Mark Blaug, Gottfried Bombach, Reiner Eichenberger, René L. Frey, Gérard Gäfgen, Arjo Klamer, Barbara Krug, Reto Jegen, Gebhard Kirchgässner, Uskali Mäki, John McMillan, Stephan Meier, Ewald Nowotny, Margit Osterloh, Bart Nooteboom, Ronan Palmer, Friedrich Schneider, Ruth Towse, Patrick van Cayseele, Harry van Dalen and Hannelore Weck-Hannemann. 
Blankart, C.B. (1981), 'Towards an Economic Theory of Advice and Its Application to the Deregulation Issue,' Kyklos, 34(1), pp. 95-105.

Blaug, M. (2002), 'Ugly Currents in Modern Economics. Fact or Fiction?', in: U. Mäki (ed.), Fact and Fiction in Economic Models, Cambridge, Cambridge University Press.

Blendon, R.J. (1997), 'Bridging the Gap between the Public's and Economists' Views of the Economy,' Journal of Economic Perspectives, 11(3), pp. 105-118.

Blinder, A.S. (1997), 'Distinguished Lecture on Economics in Government: What Central Bankers Could Learn from Academics -and Vice Versa,' Journal of Economic Perspectives, 11(2), pp. 3-19.

Brittan, S. (1973), Is There an Economic Consensus? An Attitude Survey, London, Macmillan.

Buchanan, J.M. (2000), 'Saving the Soul of Classical Economics,' Wall Street Journal, January 1st 2000.

Cassidy, J. (1996), 'The Decline of Economics,' New Yorker, December 2nd 1996, pp. 50-60.

Cicarelli, J. and L. Spizman (1984), 'The Production of Economic Knowledge,' Quarterly Review of Economics and Business, 24(2), pp. 41-50.

Clower, R.W. (1989), 'The State of Economics: Hopeless but Not Serious?', in: D. Colander and A.W. Coats (eds.), The Spread of Economic Ideas, Cambridge, Cambridge University Press.

Coase, R.H. (1994), Essays on Economics and Economists, Chicago and London, Chicago University Press.

Coats, A.W. (1981), Economists in Government: An International Comparative Study, Durham, NC, Duke University Press.

Coats, A.W. (1986), Economists in International Agencies: An Exploratory Study, New York, Praeger.

Coats, A.W. (1989), 'Economic Ideas and Economists in Government: Accomplishments and Frustrations,' in: D.C. Colander and A.W. Coats (eds.), The Spread of Economic Ideas, Cambridge, Cambridge University Press, pp. 109-118.

Cockett, R. (1995), Thinking the Unthinkable. Think Tanks and the Economic Counterrevolution 1931-1983, London, Harper Collins.

Colander, D. and A. Klamer (1987), 'The Making of an Economist,' Journal of Economic Perspectives, 1(2), pp. 95-111.

Colander, D.C. and A.W. Coats (eds.) (1989), The Spread of Economic Ideas, Cambridge, Cambridge University Press.

Cordes, J.J., A. Klamer and T.C. Leonard (1993), 'Academic Rhetoric in the Policy Arena: The Case of Capital Gains Taxation,' Eastern Economic Journal, 19(4), pp. 459-479.

Coupé, T. (2004), 'What Do We Know About Ourselves? On the Economics of Economics,' Kyklos, 57(2), pp. 197-215.

Dalen, H.J. Van (2003), Pluralism in Economics: A Public Good or Bad? Working Paper, Tinbergen Institute, University of Rotterdam.

Dalen, H.J. Van and A. Klamer (1997), 'Blood Is Thicker Than Water: Economists and the Tinbergen Legacy,' in: P.A.G. van Bergeijk, A.L. Bovenberg, E.E.C. van Damme and J. van Sinderen (eds.), Economic Science and Practice: The Roles of Academic Economists and PolicyMakers, Cheltenham, Edward Elgar, pp. 60-91.

Dasgupta, P. (1998), Modern Economics and Its Critics, Mimeo, University of Cambridge.

Demsetz, H. (1997), 'The Primacy of Economics: An Explanation of the Comparative Success of Economics in the Social Sciences,' Economic Inquiry, 35(1), pp. 1-11.

Economist (1997), 'The Puzzling Failure of Economics,' The Economist, August 23rd 1997, p. 13. 
Economist (2000), 'Economics Forum: The Future of Economics,' The Economist, March 4th 2000, p. 90.

Ehrenberg, R.G. (1999), 'The Changing Distribution of New Ph.D. Economists and Their Employment: Implications for the Future,' Journal of Economic Perspectives, 13(3), pp. 135-138.

Faulhaber, G.R. and W. Baumol (1988), 'Economists as Innovators,' Journal of Economic Literature, 26(2), pp. 577-600.

Feldstein, M. (1997), 'The Council of Economic Advisers: From Stabilization to Resource Allocation,' American Economic Review, 87(2), pp. 99-106.

Frey, B.S. and R. Eichenberger (1993), 'American and European Economics and Economists,' Journal of Economic Perspectives, 9(1), pp. 203-212.

Frey, B.S. and R. Eichenberger (1997), 'Economists: First Semester, High Flyers, and Ufos,' in: P.A.G. van Bergeijk, A.L. Bovenberg, E.E.C. van Damme and J. van Sinderen (eds.), Economic Science and Practice: The Roles of Academic Economists and Policy-Makers, Cheltenham, UK, Edward Elgar.

Frey, B.S., W.W. Pommerehne, F. Schneider and G. Gilbert (1984), 'Consensus and Dissension among Economists: An Empirical Inquiry,' American Economic Review, 74(5), pp. 986-994.

Frey, B.S. and A. Stutzer (2002), Happiness and Economics: How the Economy and Institutions Affect Well-Being, Princeton, NJ, Princeton University Press.

Friedman, M. (1972), 'Have Monetary Policies Failed?', American Economic Review, 62(2), pp. 11-18.

Friedman, M. (1986), 'Economists and Economic Policy,' Economic Inquiry, 14(1), pp. 1-10.

Fuchs, V., A.B. Krueger and J.M. Poterba (1997), Why Do Economists Disagree About Policy? The Roles of Beliefs About Parameters and Values, NBER Working Paper No. 6151, Washington DC.

Galbraith, J.K. (1975), 'Letter,' The Times, July 16th 1975, p. 12.

Garnett, R.F. (1999), What Do Economists Know? New Economics of Knowledge, London, Routledge.

Hamilton, L.H. (1992), 'Economists as Public Policy Advisers,' Journal of Economic Perspectives, 6, pp. 61-64.

Hansen, J.L. (1999), 'The Link from Graduate Education in Economics to the Labor Market,' Journal of Economic Perspectives, 13(3), pp. 147-152.

Hayek, F.A. (1991), 'On Being an Economist,' in: W.W. Bartley and S. Kresge (eds.), The Trend of Economic History, Chicago, University of Chicago Press, pp. 35-48.

Jaffe, A.B. (1989), 'Real Effects of Academic Research,' American Economic Review, 79(5), pp. 957-970.

Jones, P.R. and J.G. Cullis (1993), 'Public Choice and Public Policy: The Vulnerability of Economic Advice to the Interpretation of Politicians,' Public Choice, 75, pp. 63-77.

Journal of Economic Methodology, (2002), Symposium on the Economics of Scientific Publication, 9(3), pp. 265-396.

Journal of the European Economic Association, (2003), Symposium on Evaluating Economics Research in Europe, 1(6), pp. 1239-1423.

Joskow, P.L., R. Schmalensee and E.M. Bailey (1998), 'The Market for Sulfur Dioxide Emissions,' American Economic Review, 88(4), pp. 669-685.

Kearl, J.R., C.L. Pope, B.C. Whiting and L.T. Wimmer (1979), 'A Confusion of Economists?' American Economic Review, 69(2), pp. 28-37. 
Keynes, J.M. (1936), The General Theory of Employment Interest and Money, London, Macmillan.

Kirchgässner, G. (2005), (Why) Are Economists Different?, CESifo Working Paper No. 1396, Munich.

Klamer, A. and J. Meehan (1999), 'The Crowding out of Academic Economics: The Case of Nafta,' in: R.F. Garnett (ed.), What Do Economists Know, London, Routledge, pp. 65-85.

Klein, D.B. (ed.) (1999), What Do Economists Contribute?, New York, New York University Press.

Krueger, A.O. (1999), 'Implications of the Labor Market for Graduate Education in Economics,' Journal of Economic Perspectives, 13(3), pp. 153-156.

Krueger, A.O., K.J. Arrow, O.J. Blanchard, A.S. Blinder, C. Goldin, E.E. Leamer, R. Lucas, J. Panzar, R.G. Penner, T.P. Schultz, J.E. Stiglitz and L.H. Summers (1991), 'Report of the Commission on Graduate Education in Economics,' Journal of Economic Literature, 29(3), pp. 1035-1053.

Krugman, P.R. (1995), 'Incidents from My Career'’ in: A. Heertje (ed.), The Makers of Modern Economics, vol. 2, Aldershot, UK, Edward Elgar.

Krugman, P.R. (1996), Pop Internationalism, Cambridge, MA, MIT Press.

Layard, R. (2005), Happiness: Lessons from a New Science, New York, Penguin.

Lazear, E. (2000), 'Economic Imperialism,' Quarterly Journal of Economics, 115(1), pp. 99-146.

Leontief, W. (1971), 'Theoretical Assumptions and Nonobserved Facts,' American Economic Journal, 61(1), pp. 1-7.

Machin, S. and A. Oswald (1999), Signs of Disintegration: A Report on UK Economics Ph.D. And Esrc Studentship Demand.

Magee, S.P. (1992), 'The Optimum Number of Lawyers: A Reply to Epp,' Law an Social Inquiry, 17 , pp. $667-693$.

Mäki, U. (1999), 'Science as a Free Market: A Reflexity Test in an Economics of Economics,' Perspectives on Science, 7(4), pp. 486-509.

Mandel, M.J. (1999), 'Going for the Gold: Economists as Expert Witnesses,' Journal of Economic Perspectives, 13(2), pp. 113-120.

Mayer, T. (1993), Truth Versus Precision in Economics, Aldershot, Edward Elgar.

Middleton, R. (1998), Charlatans or Saviours? Economists and the British Economy from Marshall to Meade, Northampton, MA, Edward Elgar.

Mirowski, P. and E.-M. Sent (eds.) (2002), Science Bought and Sold: Essays in the Economics of Science, Chicago, University of Chicago Press.

Nelson, R.H. (1987), 'The Economics Profession and the Making of Public Policy,' Journal of Economic Literature, 25(1), pp. 49-91.

Peacock, A.T. (1991), 'Economic Advice and Economic Policy', in: D. Greenaway, M. Bleaney and I.M.T. Stewart (eds.), Companion to Contemporary Economic Thought, London, Routledge, pp. 713-716.

Peacock, A.T. (1992), 'The Credibility of Economic Advice to Goverment,' Economic Journal, 102(5), pp. 1213-1222.

Posner, R.A. (1999), 'The Law and Economics of the Economic Expert Witness,' Journal of Economic Perspectives, 13(2), pp. 91-100.

Prendergast, C. (1999), 'The Provision of Incentives in Firms,' Journal of Economic Literature, 37 1, pp. 7-63. 
Reder, M.W. (1999), Economics. The Culture of a Controversial Science, Chicago and London, University of Chicago Press.

Rivlin, A. (1987), 'Economics and the Political Process,' American Economic Review, 77(1), pp. 1-10. Samuels, W.J. (1980), 'Economics as a Science and Its Relation to Policy: The Example of Free Trade,' Journal of Economic Issues, 14, pp. 163-185.

Schelling, T. (1997), 'Why Does Economics Only Help with Easy Problems?', in: P.A.G. van Bergeijk, A.L. Bovenberg, E.E.C. van Damme and J. van Sinderen (eds.), Economic Science and Practice: The Roles of Academic Economists and Policy-Makers, Cheltenham, Edward Elgar, pp. 134-148.

Schultze, C.L. (1996), 'The CEA: An inside Voice for Mainstream Economics,' Journal of Economic Prespectives, 10(3), pp. 23-39.

Siegfried, J.J. (1998), 'Trends in Undergraduate Economics Degrees: A 1996-97 Update,' Journal of Economic Education, 29, pp. 285-288.

Siegfried, J.J. and W.A. Stock (1999), 'The Labor Market for New Ph.D. Economists,' Journal of Economic Perspectives, 13(3), pp. 115-134.

Stein, H. (1997), 'A Successful Accident: Recollections and Speculations About the CEA,' Journal of Economic Perspectives, 10(3), pp. 3-21.

Stephan, P.E. (1996), 'The Economics of Science,' Journal of Economic Literature, 34(3), pp. 1199-1235.

Stigler, G.J. (1982), The Economist as Preacher and Other Essays, Chicago, The University of Chicago Press.

Stigler, G.J. (1984), 'Economics - the Imperial Science?', Scandinavian Journal of Economics, 86, pp. 301-313.

Stiglitz, J. (1997), 'Looking out for the National Interest: The Principles of the Council of Economic Advisers,' American Economic Review, 87(2), pp. 109-113.

Summers, L.H. (2000), 'International Financial Crises: Causes, Preventions and Cures,' American Economic Review, 90(2), pp. 1-16.

Towse, R. and M. Blaug (1988), The Current State of the British Economics Profession, London, RES.

Wible, J.R. (1998), The Economics of Science: Methodology and Epistemology as If Economics Really Mattered, London, Routledge.

Wilke, T. (1999), 'Der Einfluss der Ökonomiscen Politikberatung: Das Beispiel der Deutschen Pflegeversicherung,' List Forum für Wirtschafts- und Finanzpolitik, 25(3), pp. 231-244.

Williamson, J. (1994), 'In Search of a Manual for Technopols,' in: J. Williamson (ed.), The Political Economy of Policy Reform, Washington, DC, Institute for International Economics, pp. 11-28.

Wypolsz, C. (1999), 'The Culture of Economic Policy Advice: An International Comparison with Special Emphasis on Europe,' in: E. Mohr (ed.), The Transfer of Economic Knowledge, Cheltenham, UK, Edward Elgar, pp. 47-73. 